Check for updates

The BMJ

fgodlee@bmi.com Follow Fiona on Twitter @fgodlee

Cite this as: BMJ2021:374:n2334 http://dx.doi.org/10.1136/bmj.n2334 Published: 23 September 2021

\title{
It is our governments' duty to protect health
}

\section{Fiona Godlee editor in chief}

The pandemic has shown how quickly and at what scale governments can act to protect health and health services. But why should it take a pandemic to achieve this? Other clear and present threats to health are all around us, and so too is the evidence that could inform rational collective action.

Climate change must come top of any list of immediate and future threats to human health. Expectations that governments preparing for the United Nations' climate change conference COP26 will now do what's needed must be tempered by past failures (bit.ly/3EO61bQ). ${ }^{1}$ But there is a lot we can and must do to keep up the pressure on our political leaders (doi:10.1136/bmj.n2177; https://healthyclimateletter.net). ${ }^{23}$ There are also things within our more direct control as health professionals that will put our own house in order by bringing healthcare's carbon emissions closer to net zero (doi:10.1136/bmj.n1323). ${ }^{4}$

High carbon societies are obesogenic, and the pandemic's lockdowns and social distancing have worsened already sky high rates of childhood obesity (doi:10.1136/bmj.n2332), ${ }^{5}$ with the grim promise of lives scarred and shortened by poor physical, mental, and emotional health. But here too there's a lot that can be done, well supported by research and real world evidence (doi:10.1136/bmj.n1716). ${ }^{6}$ We can increase access to healthy food and physical activity. We can limit marketing and raise taxes on unhealthy foods and drinks. Inevitably there has been pushback from the food and beverage industries. Less inevitably-indeed unforgivably-this has been allowed to dilute or delay regulation. Countries, including the UK, are now beginning to act but not nearly fast or furiously enough to truly have an impact on the scale of the obesity pandemic.

The imperative to reduce covid's disruption to children's lives and get them back to school has been a key factor in the UK chief medical officers' decision to recommend covid vaccines to all those aged 12-15 (doi:10.1136/bmj.n2312). ${ }^{7}$ This followed the Joint Committee on Vaccination and Immunisation's advice that the direct health benefits of vaccination were marginally greater than the risks

(doi:10.1136/bmj.n2180). ${ }^{8}$ Less well balanced seems to be the US authorities' continued unwillingness to take account of previous infection when rolling out covid vaccination (doi:10.1136/bmj.n2101). ${ }^{9}$ Increasingly draconian vaccine mandates give no currency to natural immunity, despite a growing consensus that previous infection can confer similar if not better immunity.

As for protecting the world from future pandemics, covid has shown that existing mechanisms to detect, prevent, and respond to outbreaks with pandemic potential are inadequate, writes the director general of the World Health Organization
(https://bit.ly/TedrosBMJ). ${ }^{10}$ "Covid has laid bare global shortcomings, including the grossly uneven distribution of vaccines, oxygen, diagnostics, and other tools, on the background of fragile health systems, exacerbating already existing global inequalities." He calls for greater adherence to proportional international health regulations through a legally binding accord between all the world's nations.

Whether acting together or alone, governments have a duty to protect health (10.1136/bmj.n2292), ${ }^{11}$ and we as health professionals have a duty to hold them to it.

1 Wardrope A. Putting health and climate justice at the heart of COP 26. BMJ Opinion. Dec 2020. https://blogs.bmi.com/bmi/2020/12/11/alistairwardrope-putting-health-and-climate-justice-at-the-heart-of-cop-26.

2 Wise J. Climate crisis: Over 200 health journals urge world leaders to tackle "catastrophic harm". BMI2021:374:n2177. doi: 10.1136/bmj.n2177 pmid: 34489302

3 Healthy climate prescription: An urgent call for climate action from the health community ahead of COP26. https://healthyclimateletter.net.

4 Sherman JD, McGain F, Lem M, Mortimer F, Jonas WB, MacNeill AJ. Net zero healthcare: a call for clinician action. BM/2021;374:n1323. doi: 10.1136/bmj.n1323 pmid: 34544732

5 Dyer 0. Obesity in US children increased at an unprecedented rate during the pandemic. BMJ2021;374:n2332doi: 10.1136/bmj.n2332.

6 Chung A, Tully L, Czernin S, Thompson R, Mansoor A, Gortmaker SL. Reducing risk of childhood obesity in the wake of covid-19. BMJ 2021;374:n1716. doi: 10.1136/bmj.n1716 pmid: 34376381

7 Saxena S, Skirrow H, Bedford H, Wighton K. Covid-19 vaccines for teenagers: conversations and consent. BMJ 2021;374:n2312.

8 lacobucci G. Covid-19: JCVI opts not to recommend universal vaccination of 12-15 year olds. BMJ 2021;374:n2180. doi: 10.1136/bmi.n2180 pmid: 34479872

9 Block J. Vaccinating people who have had covid-19: why doesn't natural immunity count in the US?BMJ2021;374:n2101. doi: 10.1136/bmj.n2101 pmid: 34518194

10 Ghebreyesus TA. What is the missing ingredient in global pandemic preparedness and response? BMJ Opinion. Sep 2021 https://blogs.bmi.com/bmi/2021/09/16/what-is-the-missing-ingredient-inglobal-pandemic-preparedness-and-response.

11 McKee M. Has the UK government given up the fight to protect and promote health?BM/2021;374:n2292.

This article is made freely available for use in accordance with BMJ's website terms and conditions for the duration of the covid-19 pandemic or until otherwise determined by BMJ. You may use, download and print the article for any lawful, non-commercial purpose (including text and data mining) provided that all copyright notices and trade marks are retained. 